\title{
Orientalisation through Paratexts: The Covers of Muslim Memoirs
}

\author{
Esmaeil Zeiny Jelodar ${ }^{1}$, Noraini Md. Yusof ${ }^{1}$, Ruzy Suliza Hashim ${ }^{1}$, Shahizah Ismail Hamdan ${ }^{1}$ \& Raihanah M. \\ M. ${ }^{1}$ \\ ${ }^{1}$ School of Language Studies and Linguistics, National University of Malaysia (UKM), Bangi, Selangor, \\ Malaysia \\ Correspondence: Esmaeil Zeiny Jelodar, School of Language Studies and Linguistics, National University of \\ Malaysia (UKM), 43600, Bangi, Selangor, Malaysia. Tel: 60-1-7281-5502. E-mail: mehdizeiny@gmail.com
}

Received: June 4, 2013 Accepted: July 8, 2013 Online Published: September 29, 2013

doi:10.5539/ass.v9n13p169

URL: http://dx.doi.org/10.5539/ass.v9n13p169

\begin{abstract}
The influx of memoirs by and about Iranian women has saturated the post-9/11 Western literary market. These memoirs, which emerged after 9/11 and the President Bush's 'Axis of Evil' speech addressed to Iran, North Korea and Iraq, are written to quench the curiosity of the Western readers. However many of these memoirists have adopted Western Orientalism framework in writing their discourse. They use the Iranian psyche, people, culture and religious worlds to reproduce the Western bias against the 'Other.' This portrayal of Western Orientalism 'otherness', which oftentimes begins right from the covers of the memoirs, can be called orientalisation through paratexts.
\end{abstract}

Keywords: memoir, orientalisation, other, western, Iran

\section{Introduction}

The Iranian Revolution of 1979 was the main reason for the influx of Iranian emigration and later on the explosion of writings by Iranian women in exile. Almost all of these writings are memoirs and deal with issues facing women in an Islamic society. This extraordinary blooming canon of memoirs by and about Iranian women has monopolized the post-9/11 Western literary markets. These Iranian diasporic life narratives are in great demand in the West and they seem to satisfy the inquisitiveness of Western readers about the life of women in Iran. What sparked this curiosity was partly due to the fact that traditionally people in the West have always been interested in learning the cultures of the East, but noticeably their inquisitiveness was enticed after the President Bush's 'Axis of Evil' speech addressed to Iran, North Korea and Iraq. Notwithstanding a great number of memoirs for the Western readers' consumption, the Western publishing houses keep publishing these memoirs thick and fast.

The event of 9/11 and the consequent President Bush's 'Axis of Evil' speech provided favorable circumstances for the authors of these life narratives to voice their heart and become the voice of Iranian women. They took the chance and started to recount their stories in the form of a memoir. These memoirs, which are written to unfold the lives of women in Iran, provide Western readers with Orientalist accounts of Muslim women as veiled, powerless, silent, abused and victims of a patriarchal society. There is a persistent proclivity amongst these writers to depict their own country, people and Islam through orientalist spectacles. These stories are usually one-sided and generalized; it is like 'one woman's story is every woman's story' approach (Fotouhi, 2012). The authors use the Iranian psyche, culture and religious worlds to regenerate the Western prejudice against the 'Other' and hand it over to the West for financial profit. Appropriating the Western Orientalism framework in their discourse, these women memoirists are involved in further orientalisation of their own country. These life narratives, which have the power to transform people's ideas, represent the lives of Iranians as the 'Other' to the West. The memoirists and the western publishing houses, usually, initiate to portray the West/East dichotomy right from the covers of these memoirs; this can be called orientalisation through paratexts.

Paratexts are the features that surround and cover the texts; following Gerard Genette (1997), Whitlock (2007) distinguishes two elements: "peritext" contains everything between and on the covers, and reading the covers of these life narratives are of paramount importance here; and "epitext" includes the elements outside the volume such as interviews, correspondence, reviews, and commentaries. Whitlock (2007) believes that these life narratives are potent and paradoxical things. Readers are aware of this fact even without taking them off the shelf of a book store. She refers to Genette (1997) for the thorough explanation of paratexts. She argues that in his 
study of paratexts, Genette (1997) talks about the "work that books do on the shelf", and he also makes a useful differentiation between the "public and the readers as different addressees" (2007, p. 56). Genette is of the idea that the "public is not the totality or sum of the readers" (cited in Whitlock, 2007, p. 56). He believes that we participate in life narratives dissemination and 'reception' and absorb them even when we are sitting at a conference and watching a PowerPoint display of covers, or even just walking into an airport bookstore. Then, he calls these people an addressee even though they might not become a reader. By concentrating on texts as a product and a commodity, Genette (1997) focuses on some momentous features when one looks at a life narrative: the cover, the title and the subtitle, pseudonyms, prefaces, maps, endorsements, blurbs, and notes. These are called peritexts and are the first contact between the prospective reader and the text. Publishers place importance on them as one of the first strategy to sell the books.

The boundaries between the text and the reader of these life narratives from the Middle East signify complicated conciliation between the "autobiographical subject, the publisher, the public, and the reader" (Whitlock, 2007, p. 57). As Philippe Lejeune suggests, given the way the fringe of the printed text control its reception, it is a strategic effort to engender a legitimate reading (quoted in Genette, 1997, p. 2). A life narrative is particularly priceless in the market economy, and its distribution in the public sphere is always cautiously handled. From this explanation, it can be understood why these life narratives from the Middle East are all inundated with peritexts: the endorsement of others. Many of them feature maps; the political geography of the Middle East, Iran, Iraq, and Afghanistan with a particular stress on their location in relation to the United States of America. Whitlock (2007) opines that one cannot speak of the authors of these life narratives as "they are stories told to and shepherded by advocates" (2007, p. 57). The covers of Muslim life narratives are often replete with endorsement from writers and dignitaries including Alice Walker, Margaret Atwood, Dan Rather, Katha Pollitt, and Arundhati Roy who are voices of authority in the West, especially in the United States as a primary market. Walker and Roy, as women of color, have particular roles in legitimizing these subaltern narratives in the North American market (Whitlock, 2007, p. 58). The covers of life narratives from Iran also feature endorsements: Margaret Atwood on Nafisi's Reading Lolita in Tehran (2003) and Gloria Steinem, the American feminist, journalist, and social and political activist, on Satrapi's Persepolis: The Story of a Childhood (2003).

As parts of paratexts, the images, the titles and the subtitles on the covers of these life narratives are called peritexts; they all adhere to the Western Orientalism framework. The depictions, the titles, and subtitles of these narratives are all devised to capture the Western eye with a glance of absolute difference, of the exotic. Fotouhi (2012, p. 29) believes that "titles and covers, blurbs and promotions for these books often draw on notions of silence, veiling and unveiling, oppression and imprisonment, highlighting the acute difference between women's lives over 'there' and here." She continues that more than half of the Iranian women's memoirs possess an identical cover image of women clad in a veil or chador; most of them depict "a woman's half-veiled face, only her eyes showing, piercing and staring at the audience" (29). These images are all "inviting and yet challenging the viewer / reader to pick up the book to enter into their mysterious, hidden world" (Fotouhi, 2012, p. 29). Whitlock (2007) believes that this is a stratagem for positioning them in a cosmopolitan market. Taking on from this trajectory of book images, this paper examines the covers of three Iranian diasporic memoirs: Reading Lolita in Tehran (2003), Persepolis (2001, 2002 \& 2003) and Journey from the Land of No (2004) written by Azar Nafisi, Marjane Satrapi and Roya Hakakian respectively.

\section{Reading Lolita in Tehran}

Right from the start, Nafisi establishes a binary opposition. For instance, the title of Reading Lolita in Tehran attracts the readers by initiating this opposition. "Lolita" stands for the West; "Tehran" connotes Islamic theocracy and oppressed Muslim women. This life narrative links these two worlds together for both the women in the memoirs and the readers of the memoir. By using "Lolita", Nafisi sensationalizes the Iranian women's situation. The title is traumatic in the Iranian context and enticing in a Western one. Even the illustration of the cover - two young women wearing headscarf with heads bent forward, staring at an object (presumably a book) adds to the predictable marketing package by catering and pandering to the Western audience's expectation (Abbott, 2004, p. 106). What exactly they are reading is hidden from view. Above the picture, it reads "Reading Lolita in Tehran". The immediate suggestion that comes to mind is that these two young women are reading "Lolita" in Tehran (Dabashi, 2011). 


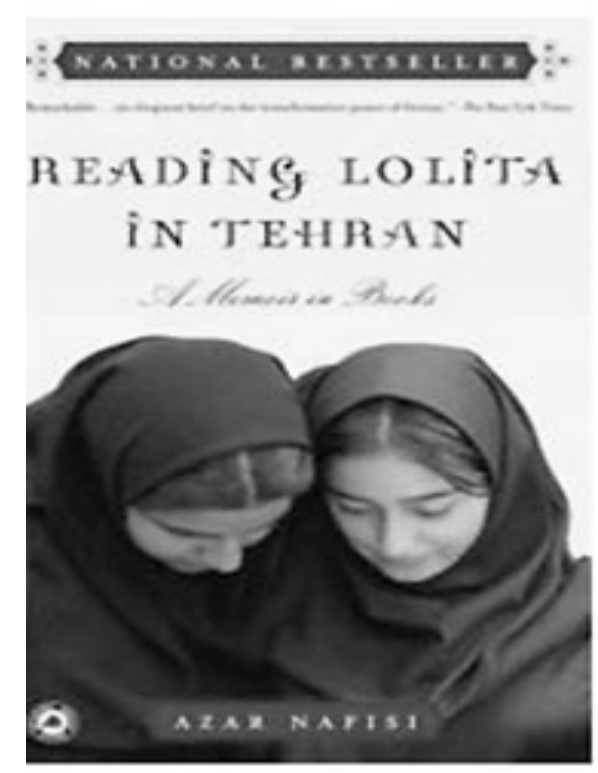

Figure 1. The cover of reading Lolita in Tehran (2003)

However, Dabashi (2011, p. 75) argues that the illustration of the cover "is an iconic burglary from the press, distorted and staged in a frame for an entirely different purpose than its original circumstances". The photo is cropped so that the readers do not see the newspaper. In the actual picture, the two girls were reading the result of a major parliamentary election. Thus, Reading Lolita in Tehran's scratched depiction of 'truths' starts right from the very beginning on the cover of the text; this tainted beginning accentuates the fact that she has adopted the Western framework in her discourse. The doctored image of the veiled women on its cover epitomizes Nafisi's entire work.

To further substantiate his points, Dabashi (2011) gives a comprehensive analysis of the cover of Nafisi's text. He believes that "because comprador intellectuals ...operate within the middle-class morality of their host country (now mutated into an empire) innuendo and insinuation are among their principal tools" (2011, p. 73). On the image and caption on the cover of the text, he is of the idea that the reading of Vladimir Nabokov's Lolita in the city of Tehran and the image that shows two hijab-clad girls happily preoccupied with reading it solicit sympathy and even complicity. The image along with its caption implies the alluring addition of an Oriental in an instance of a classical example analyzed by Roland Barthes (1977) in his brilliant essay 'The Photographic Message'. The term 'Lolita', as a social sign and as a literary signifier, suggests illegal sex with teenagers, which is the addictive gratification of an old man with a young girl. Dabashi claims that the image of the two girls wearing headscarves "suggestively borrows and insidiously unleashes an Oriental fantasy and binds it to the most lurid case of pedophilia in the modern literary imagination" (2011, p.74). Barthes, under the rubric of photographic paradox, suggests a coruscating diagnosis of the way an imitative art like photography consists of two inscriptions: "a denoted message, which is the analogon, (a photograph or a sketch), itself, and the connoted message, which is the matter in which the society to a certain extent communicates what it thinks of it" (Barthes, 1982, pp. 195-198). On the denoted and the connoted messages of this image and the caption on the cover of Nafisi's text, Dabashi $(2011$, p. 74) asserts that:

The denoted message here seems quite obvious: These two young women are reading Lolita in Tehran. They are reading the novel Lolita and they are in Tehran (they look Iranian and they have headscarves on). The connoted message is equally obvious: Imagine - illicit sex with teenagers in the Islamic Republic! How about that! The cover proposes suggestively. Can you imagine reading Lolita in Tehran? Look at these two Oriental Lolita! The racist implication of the suggestion-also implicit in the astonishment of asking, "Can you ever imagine reading that novel in that country?" -competes with the Orientalized pedophilia and confounds the barefaced transparency of a marketing strategy that appeals to the most deranged Oriental fantasies of a nation already scared out of its wits by a ferocious war against a phantasmagoric Arab/Muslim male potency that has just castrated the two totemic phalluses of the American empire.

The girls have been unknowingly constructed into a representation. Dabashi puts it best when he says the 
portrayal of the two girls on the cover suggests "the erotic infantilization of the Orient" (2011, p. 74). One of the stereotypical depictions in multitude Orientalist paintings is the desire to stage under-aged man and woman. The cover of Nafisi's life narrative is an extension of an established tradition in Orientalist drawings and colonial postcards like that of Arthur Bridgman's 'Algerian Girl' (1888) and his 'Harem Girl' (n. d.) and the whole genre of colonial picture postcards of young Algerian women which was produced, staged and brought by French colonial officers. Malaek Alloula, in his The Colonial Harem (1987), studies the colonial photographs and reveals how the pathological colonial apparition produced and kept what Barthes called the 'degree zero' of photographic proof to represent and own the colonized figure. The Orientalist Westerners and the Oriental array of native informers try to keep the Orient at this cradle state as they fear that once these boys and girls likewise reach maturity, they will abhor their imperial torturers and castrate their phallic claims to power (Dabashi, 2011, p. 75).

Dabashi (2011) argues that the cover of Nafisi's Reading Lolita in Tehran does more than colonial provocation; it changes Barthes' binary opposition of the denoted and connoted inscriptions of the picture and its caption. The change and the twist rest on the fact that the image of the two teenage girls is taken from an absolutely different context. It certainly is not about the girls reading a novel. It has been abducted from a news report archived during the parliamentary election of 2000 and shows these girls reading Mosharekat, a leading reformist newspaper. Kidnapping the image from the newspaper to suggest that the two girls were in fact reading the novel Lolita is, "to say the very least, highly questionable" (Dabashi, 2011, p. 75). The following images are taken from Dabashi's Al-Ahram essay 'Native informers and the making of American empire' (2006) to provide examples of colonial postcards and to reveal the true picture of the two girls on the cover of Nafisi's text.

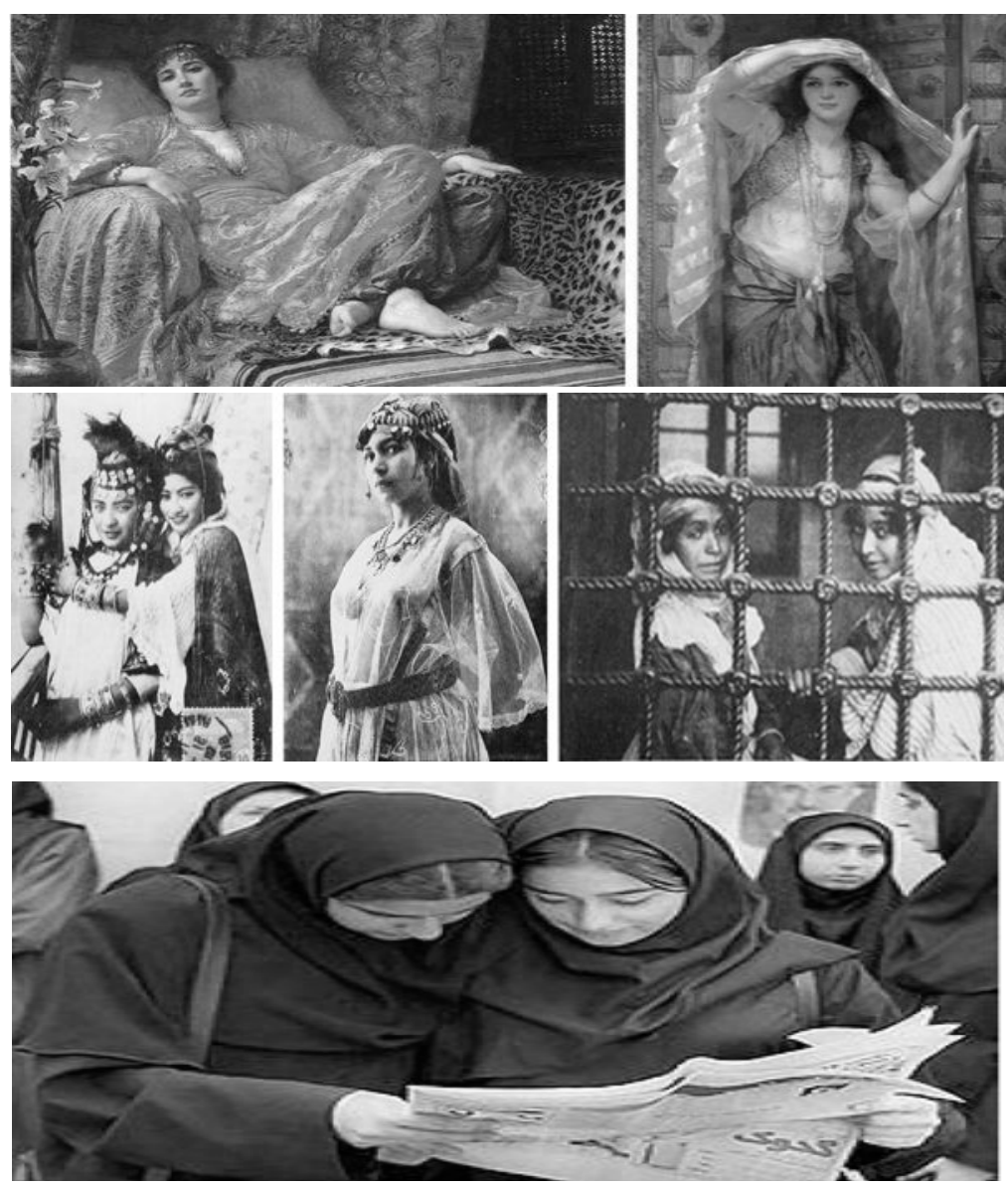

Figure 2. The orientalist paintings, the colonial postcards, and the original picture from which the cover of reading Lolita in Tehran was cropped

On the back cover of Nafisi's text, the narrative is endorsed by three prestigious and well-known authors. This is the peritext Whitlock (2007) refers to in her book which in fact authenticates the author of the narrative. These authors are hand-picked as they are very well-known to the Western audiences. The first author is Margaret 
Atwood and to give authentication to Nafisi's text, she states that "All readers should read it ... engrossing, fascinating, stunning". Margaret Atwood is a Canadian poet, novelist, literary critic, and essayist. She has won many literary awards including the Arthur C. Clarke Award and Prince of Asturias award for Literature, Booker Prize and the Governor General's Award twice. Another author whose assertion of "Anyone who has ever belonged to a book group must read this book" assists the commercialization of the book is Geraldine Brooks, an Australian-American journalist and author whose novel March (2005) won the Pulitzer Prize for Fiction. Susan Sontag's endorsement phrase "I was enthralled and moved" has the same role of legitimizing and authentication of Nafisi as she is an American essayist, literary icon, and political activist who won many awards; to name few of the awards: National Book Critics Circle Award, Malaparte Prize, Italy, Commandeur de l'Ordre des Arts et des Lettres, France National Book Award. Their endorsements are the push factors that create a big circle of readership, and by aligning with the legitimate reviewers, the readers are then made to feel that they share similar literary finesse.

\section{Persepolis: The Graphic Memoir}

This section concentrates on the covers of Satrapi's Persepolis both in French and in English. Satrapi's graphic memoir succeeded a great deal not only because of its topicality and its geopolitical climate but also because of its clever packaging and marketing strategies. The covers of her graphic memoir carry a different portrayal between French and North American publication. The images on the French publications have got nothing to do with the veil but they are orientalist drawings; Persepolis 1 depicts a man carrying a dagger mounted on a muscular horse. The figure looks like a Persian man out of a historical text. He is facing East on the cover presumably in a position of attack.

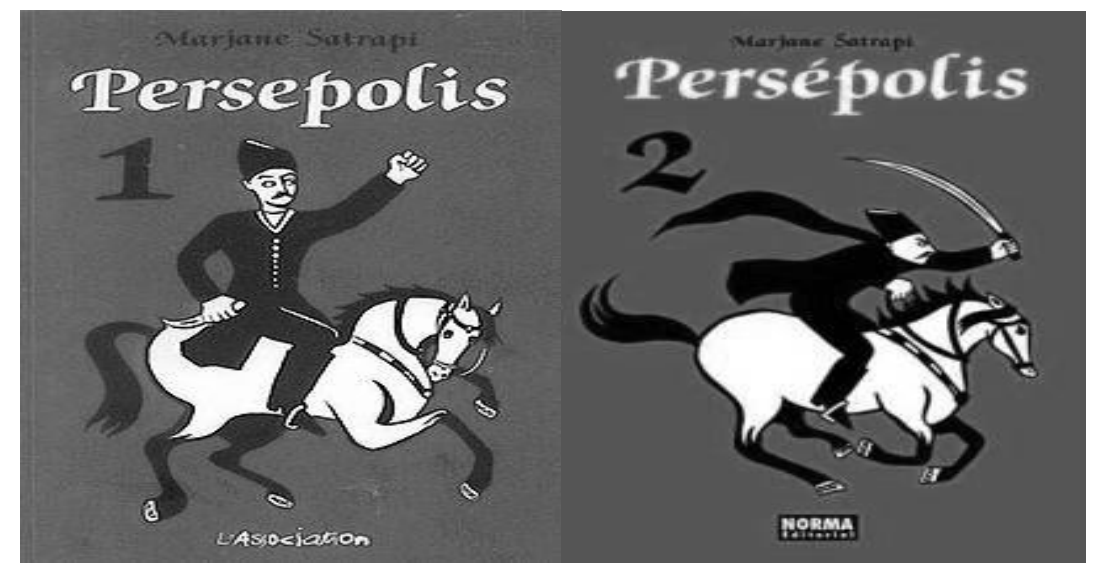

Figure 3. From persepolis volume $1 \& 2$, L'Association, Paris, France (2001) and (2002)

Persepolis 2 also portrays a man mounted on a horse but carrying a sword. He is depicted facing East as well but now galloping in the middle of a battlefield. Both depictions are portrayed under the title: Persepolis. Persepolis, which was the ceremonial capital of the Achaemenid Empire (ca. 550-330 BCE), stands for Iran. These images under the title suggest that these men are attacking their own people as Iran is situated in the East. The figures on the covers, indeed, stand for the Iranian authorities. By looking at the covers, the Western readers may be led to wonder why Persians attack their own people; hence, their curiosity is aroused. It could be argued that these depictions are portrayed to pander and cater to the Western markets and persuade the Western readers that Iran needs to be liberated from the brutality of its government. Right from the beginning of the memoir, on the cover, Satrapi creates the justification for imperialism's intervention that Dabashi (2011) refers to and in convincing the Western people that it is time to save the country from its government. 


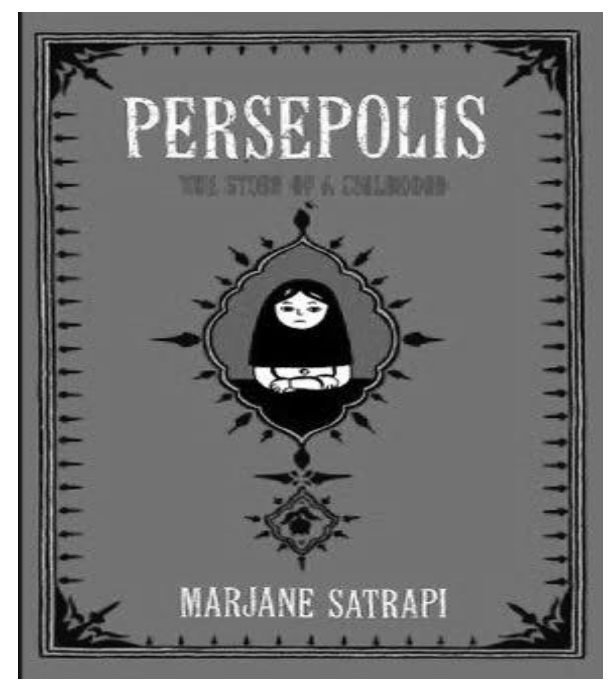

Figure 4. From persepolis: the story of a childhood. New York: Pantheon (2003)

In the North American version above, Persepolis: The Story of a Childhood, Satrapi employs an important issue in depicting the image on the cover: the veil. She depicts a simple black and white image of her own childhood, an unsmiling Marji. She is portrayed with a veil that covers her head, shoulder and breast. She sits with her arms crossed and the strands of her bangs are shown with highlights in them. Her frowning expression shows that she is unhappy with her current status. The exposure of the strands of her hair suggests that she is resisting against the mandatory veiling and the highlights in them stand for freedom which she longs for. This depiction also goes under the title of Persepolis. To invoke the image of the Middle East, the depiction of Marji is centered on a red book-cover with black patterns. Many critics argue that "this cover reinforces a female Muslim identity and stereotype and presents the idea of Western humanitarian actions by inviting the reader to hear a more intimate story than other media have presented" (Barzegar, 2012, p. 20). Like its two covers in French, this cover is also recruited to invoke the curiosity of the Westerners to find out why she is depicted unsmiling.

Like the other memoirs, Satrapi's graphic memoir is also endorsed by famous authors and publishers in the West. These endorsements on the book' covers authenticate the author and encourage the Western readers to read the book. This is the peritext Whitlock (2007) refers to as a marketing strategy. The graphic memoir is first authenticated by Philip Pullman. In praising the work of Satrapi, he asserts that her memoir is "a superb piece of work. Satrapi shows us how growing up takes place in a society ruled by rigid religious dogma...You can see the presence of other predecessors: the Hernandez brothers, Frans Masereel, Art Spiegelman." Reading these words from Pullman, who has been named one of the 50 great British writers since 1945 and a person who has won many different awards for his bestselling books and illustrations, can be quite convincing for the Western readers to read the graphic memoir. Moreover, the fact that he compares the book to its other predecessors, such as Art Spiegelman, offers wider readership as Spiegelman is a well-known figure in the West for his pioneering work. Following Pullman, Gloria Steinem, an American feminist, journalist, and social and political activist, authenticates Satrapi by her approval of the work. She states that "you've never seen anything like Persepolis... Marjane Satrapi may have given us a new genre." Steinem uses quite powerful words in describing Satrapi's work: "you've never seen anything like Persepolis" and "a new genre" are all inviting the Western readers to read the memoir.

Presuming that there is a large Mexican-American community in America, Satrapi uses Sandra Cisneros, an American-Mexican writer, to widen her audiences and to legitimize her graphic memoir. As a recipient of numerous awards, Cisneros states that "I grew up reading the Mexican comics of Gabriel Vargas...fell under the spell of Linda Barry and Art Spiegelman, and now I am a fan of Marjane Satrapi. Part history book, part Scheherazade, astonishing as only true stories can be, Persepolis gave me hope for humanity in these unkind times." Cisneros gives an explicit authentication by confirming the book as a true story. Another author whose statement of "I cannot praise enough Satrapi's moving account of growing up as a spirited young girl in revolutionary and wartime Iran..." helped the graphic memoir to gain authentication is Joe Sacco, an American comic artist and journalist and the famous award winner for his work Palestine (1996). The last author who is equally important in authenticating the graphic memoir is Hanan al-Shaykh, the author of Women of Sand and 
Myrrh (1992) and Only in London (2001). As a Lebanese author based in England and as a woman who has suffered oppression in a patriarchal society of her country, she asserts that "blending the historical with the personal is not an easy task...This graphic novel is a reminder of the human spirit that fights oppression and death." Al-Shaykh's assertion confirms that people, especially women, face oppression in the Middle East which in turn consolidates Satrapi's work as a true memoir. As a marketing strategy, these assertions not only help the book to sell like hotcakes but also assist the author to become a reliable figure for her readers.

\section{Journey from the Land of No}

The cover image of this life narrative by Hakakian is what resembles the cover image of Marina Nemat's Prisoner of Tehran (2007) but with a white veil. The same set of eyes and eyebrows of a woman is used for the image of the cover. It portrays a woman's half-veiled face, only her eyes and half of her eyebrows are showing, staring at the spectators. The sharp look of the eyes in these depictions which differentiates each woman from the other beneath the veil, according to Fotouhi $(2012$, p. 29), is a "humanising strategy" suggesting that the veiled woman "can look back at the spectator mute but eloquent" (Whitlock, 2007, p. 59). This Eastern like gloomy set of eyes is depicted to implore the Western readers to liberate women living in Islamic societies. This look seems inviting and encouraging to the "Western imperial gaze, offering Westerners a glimpse into the presumably forbidden world beneath the veil" (Whitlock, 2008, p. 81).

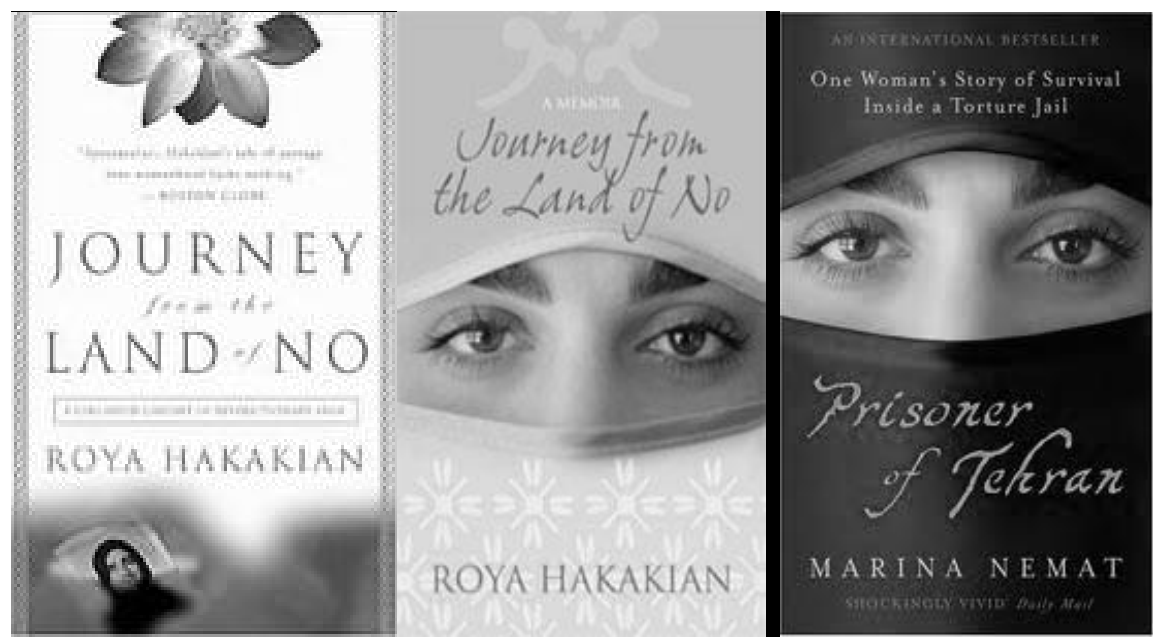

Figure 5. The covers of journey from the land of No (2004) \& prisoner of Tehran (2007)

Like the image on the cover, the title and subtitle are captivating to a Western eye as well. Journey from the Land of No accompanied by 'a Girlhood caught in Revolutionary Iran' as a subtitle makes the cover interesting and appealing to Western readers. Just like the other life narratives, Journey from the Land of No (2004) is also endorsed and sanctioned by well-known and prestigious figures such as Letty Cottin Pogerbin, author of Three Daughters (2003). In praising the life narratives, she asserts, "[a]n adolescent memoir of remarkable vividness and narrative grace, Hakakian's account of her life as a Jewish girl in revolutionary Iran sounds uncanny echoes from today's headlines in the Middle East..." Pogerbin is an American author, journalist and a social justice activist; her words legitimize the memoir and create a wide circle of readership. Author of Jihad: The Rise of Militant Islam in Central Asia (2002), Ahmed Rashid, describes the life narrative as "[a]n amazing, moving debut. Hakakian's words of lost innocence and experience sing out from the pages. A heady mixture of Islamic fundamentalism, revolutionary politics, and the pains of growing up in Tehran perfectly and lyrically expressed." As a marketing strategy, all these assertions which confer legitimacy to the life narrative are of paramount significant in making the author a reliable figure.

\section{Conclusion}

Many memoirs on Iran, Iranians and Iranian women have been saturating Western bookstores since 9/11. These memoirs which shape and metamorphose ideas represent Iranians as the 'other.' The authors and publication houses of these memoirs commence to portray the 'otherness' right from the covers of the text. The peritexts which include images, titles, subtitles, endorsements, blurbs, notes and prefaces are all devised to capture Western readers' attention. All these images and captions are recruited only to pander and cater to the Western market and to convince the Western readers that Middle Eastern women need to be liberated from the savagery 
of Muslim man. By looking at the covers, Western readers get the sense of wanting to liberate women from the savagery of the authorities. Consequently, these authors become agents in further orientalisation of their own country.

\section{References}

Abbott, C. (2004, January 26). Books Lovers of The World Unite: Will Reading Lolita in Tehran Become One of The Year's Biggest Book Club Readers? Publishers Weekly.

Alloula, M. (1987). The Colonial Harem. Manchester University Press.

Al-Shaykh, H. (1992). Women of Sand and Myrrh. Anchor.

Al-Shaykh, H. (2001). Only in London. Bloomsbury Publishing PLC.

Barthes, R. (1977). Roland Barthes by Roland Barthes. Translated by Richard Howard. New York: Hill and Wang.

Barzegar, L. (2012). Persepolis \& Orientalism: A critique of the reception history of Satrapi's memoir. Colorado State University. Master thesis.

Brooks, G. (2005). March. Viking.

Dabashi, H. (2006, January 1). Native informers and the making of American empire. Al Ahram Weekly.

Dabashi, H. (2011). Brown Skin, White Mask. New York: Pluto Press.

Fotouhi, S. (2012). Self-orientalisation and reorientalisation: a glimpse at Iranian Muslim women's memoirs. International Center for Muslim and non-Muslim Understanding.

Genette, G. (1997). Paratexts: Thresholds of Interpretation. Cambridge: Cambridge University Press. http://dx.doi.org/10.1017/CBO9780511549373

Hakakian, R. (2004). Journey from the Land of No. Bantam, Auckland.

Nafisi, A. (2003). Reading Lolita in Tehran. New York. Random House.

Nemat, M. (2007). Prisoner of Tehran. Simon \& Schuster. New York.

Pogerbin, L. C. (2002). Three Daughters. Farrar. Straus and Giroux publication.

Rashid, A. (2002). Jihad: The Rise of Militant Islam in Central Asia. Yale University Press.

Sacco, J. (1996). Palestine. Fantagraphics.

Satrapi, M. (2003). Persepolis: The Story of a Childhood. New York: Pantheon Books.

Whitlock, G. (2007). Soft Weapons: Autobiography in Transit. Chicago, University of Chicago press. http://dx.doi.org/10.7208/chicago/9780226895277.001.0001

\section{Copyrights}

Copyright for this article is retained by the author(s), with first publication rights granted to the journal.

This is an open-access article distributed under the terms and conditions of the Creative Commons Attribution license (http://creativecommons.org/licenses/by/3.0/). 